\title{
Location and Roles of Deep Pools in Likangala River during 2012 Recession Period of Lake Chilwa Basin
}

\author{
Rodgers Makwinja, ${ }^{1}$ Mphatso Chapotera, ${ }^{2}$ Patrick Likongwe, ${ }^{2}$ \\ John Banda, ${ }^{2}$ and Asaf Chijere ${ }^{2}$ \\ ${ }^{1}$ Department of Fisheries Science, Mzuzu University, P/Bag 201, Luwinga, Mzuzu 2, Malawi \\ ${ }^{2}$ World Fish Center, P.O. Box 229, Zomba, Malawi \\ Correspondence should be addressed to Rodgers Makwinja; makwinjarodgers@gmail.com
}

Received 13 November 2013; Accepted 12 May 2014; Published 3 June 2014

Academic Editor: Pavlos Kassomenos

\begin{abstract}
Copyright (C) 2014 Rodgers Makwinja et al. This is an open access article distributed under the Creative Commons Attribution License, which permits unrestricted use, distribution, and reproduction in any medium, provided the original work is properly cited.

The ecological study focusing on Likangala River was conducted during the recent (2012) Lake Chilwa recession and aimed at identifying the important pools and the impact of indigenous ecological knowledge on the use and management of the aquatic biodiversity in the pools. An extensive georeferencing of the pools, field observations, and measurement of the pool depths was conducted to locate and map the deep pools along the river. Garmin Etrex Venture HC, GPS, and georeferencing were used to obtain the points and locate the place. Oral interviews with local leaders were conducted to understand the use and management of the pools by communities. The study showed that Likangala River has 17 pools with depths ranging from $1.85 \mathrm{~m}$ to $3.6 \mathrm{~m}$. The pools act as habitats and feeding and spawning ground for various aquatic biodiversity. The study further found that some important deep pools have apparently become shallower during the past few years due to increased silt deposition from the upper part of the catchment. The study shows that deep pools are very important during Lake Chilwa recession and recommends the participatory fisheries management as the best way of sustaining the aquatic biodiversity and endangered species in Lake Chilwa basin.
\end{abstract}

\section{Introduction}

Lake Chilwa is among the most productive aquatic ecosystems in the tropics. The Lake fishery is very important to Malawi's economy and contributes on average around 15,000 MTyear $^{-1}$. The socioeconomically important land use practices of Lake Chilwa include: fishing, agriculture (wetland rice cultivation, dimba cultivation, irrigated rice cultivation, and livestock), and human settlements. The lake has three important fish species: the cyprinid Barbus paludinosus, the (catfish) clariid, Clarias gariepinus, and the only endemic fish of the lake, a mouth breeding cichlid, Oreochromis shiranus chilwae, which supports over 5,000 small scale fishers on the lake landing in Zomba, Machinga, and Phalombe districts (GoM, 2011) [1].

Studies on the lake level of Lake Chilwa have shown that the lake has gone through moderate recession during the years 1900, 1923, 1931, 1943, 1949, 1953/55 and 1960/61 and severe recession resulting in dry 1941/45, 1966/65 and 1995
(Nyasulu et al., 2001) [2] leaving water in the river mouths and deep pools in the wetland (Jamu, 2011) [3]. Several studies focusing on Likangala River have been conducted in the past few years. For instance, Mulwafu (2000) [4] studied conflicts over water use in Malawi: A social-economic study of water resources management along Likangala River in Zomba District. Mulwafu and Nkhoma (2001) [5] further studied the use and management of water in the Likangala irrigation scheme complex.

Jamu et al., (2005) [6] studied the impacts of land use and cover changes in the Likangala catchment of the Lake Chilwa basin, Malawi with emphasis on implications for migrating fish species. However none of the studies addressed the significance of the pools during the lake recession and the impact of the indigenous ecological knowledge of the communities around on the management of the pools. Hence the present study aimed at locating pools along the river, understanding the significance of the pools to aquatic biodiversity during lake recession and the impact of the indigenous 


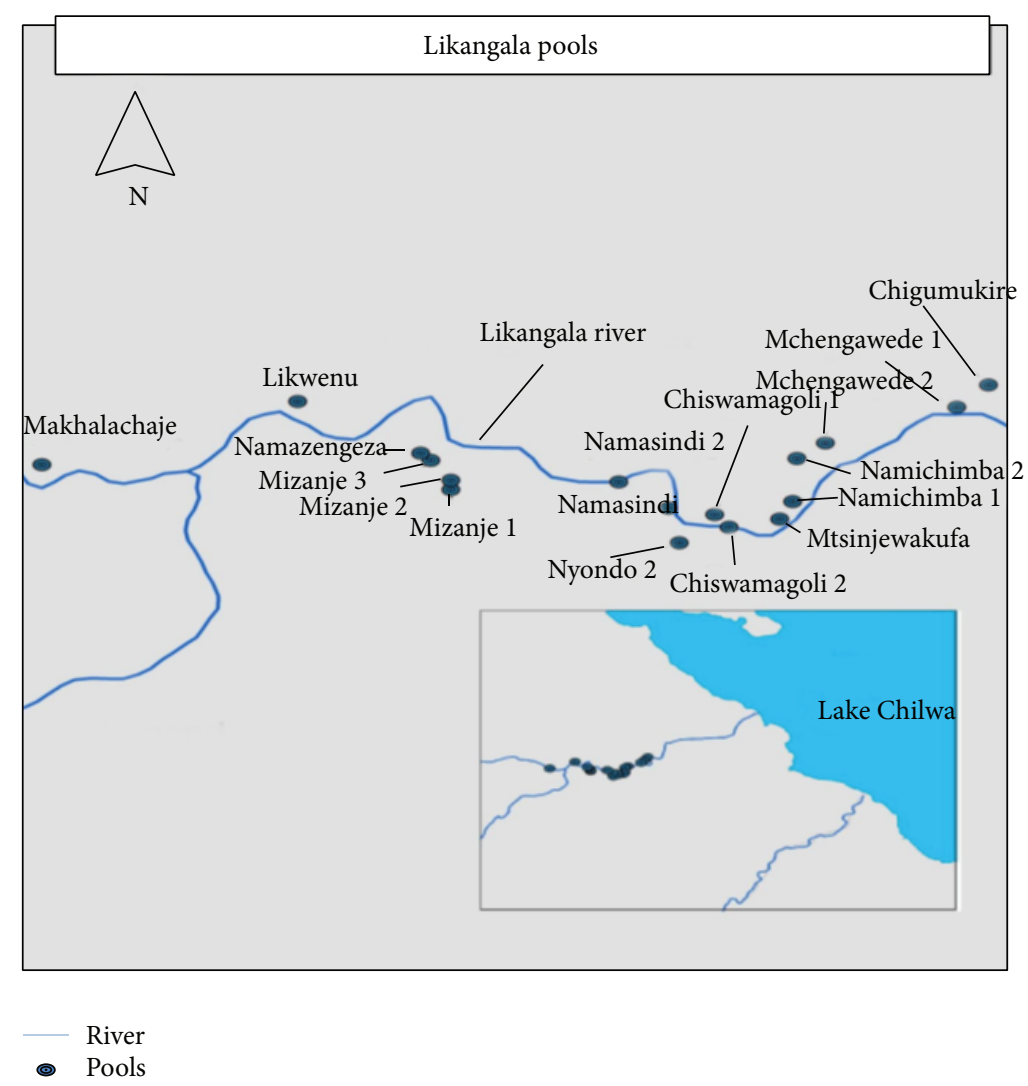

Figure 1

ecological knowledge of the communities around on the use and management of the pools.

\section{Materials and Methods}

The study was focused on Likangala River which drains into Lake Chilwa, a basin lake with total area of $2248 \mathrm{~km}^{2}$, an altitude of 622 meters above sea level, and maximum depth of less than 5 meters, which is situated between Latitudes $15^{\circ} 00^{\prime} \mathrm{S}$ and $15^{\circ} 30^{\prime} \mathrm{S}$ and Longitudes $35^{\circ} 30^{\prime} \mathrm{E}$ and $35^{\circ} 55^{\prime} \mathrm{E}$ in the centre of the low-lying Chilwa-Phalombe plain in Southern Malawi [7].

An extensive georeferencing of the pools, field observations, and measurements of the pools' depths was carried out to locate and map the deep pools which are found along the river. The depth of the pool down to the bottom was measured using a demarcated rope and a sinker tied to the end of the rope. The rope was demarcated in meters on the ground using a tape measure before being connected to the sinker. Garmin Etrex Venture HC, GPS, and Georeferencing were used to obtain the points and locate the place.

The data was entered in Microsoft Excel before being exported to ARC View GIS for mapping. Oral interview with local communities around was conducted in order to understand the impact of indigenous ecological knowledge of the communities on the use and management of the pools.

\section{Results and Discussion}

Results describing the location of the pools in Likangala River are presented in Figure 1.

The current study found that Likangala River has 17 pools with depth ranging from $1.85 \mathrm{~m}$ to $3.6 \mathrm{~m}$. The deep pools serve as dry season refuge for many aquatic biodiversity. The study further found that the pools are important habitats for migrating fish species such Barbus species which spawn at the mouth of the rivers.

Many local communities have recognized their importance in fisheries terms and have established management measures to protect them.

The present study agrees with the work of Kalanda-Sabola (2007) [8] who observed that local people have the potential to provide accurate ecological knowledge of managing the aquatic biodiversity. Kalanda-Sabola (2007) [8] further reported that communities are able to analyse situations and interpret the results using their practical experience of tackling problems and perspective of having an overview of a subject or issue. Moller et al. (2004) [9] further reported that a few simple rules suggested by indigenous knowledge may produce good management outcomes consistent with fuzzy logic thinking.

The local communities around these important pools established River Village Committees (RVCs) with the 
Department of Fisheries under COMPASS II (Community Partnerships for Sustainable Resource Management) project in May 2009 [1, 10].

The association can issue permits to fishermen to fish in pools and prohibit the use of illegal fishing gear, which does much damage to fishery [11]. They also prohibit malpractices of fishing juveniles before they can breed and destruction of mangroves around the river, which are essential for breeding. A participatory fisheries management (PFM) agreement which was formed transfers the ownership of fisheries resource to the fishermen who use them.

It gives the right and responsibility to manage the fisheries' sustainably. It is believed that participatory fisheries management in the rivers will signal a revival of the once thriving fishing industry which is so essential to the economy of the nation and to the livelihoods of rural households within Lake Chilwa basin [12].

The study found four main fish species which spawn in the pools. These are Barbus paludinosus, Barbus trimaculatus, Clarias gariepinus, Tilapia rendalli, and Oreochromis shiranus chilwae which are locally known as Matemba, Mlamba, Chilunguni, and Makumba, respectively. The larvae and juveniles move downstream to the marshes and marginal swamps in Lake Chilwa to grow.

Further downstream, near the river mouth there are several important deep pools actually named by locals after the main dangerous animals living in them including poisonous snakes and aquatic mammals. They are given special attention and are referred to as sacred places. These pools are important feeding and spawning grounds for several species, such as Hippopotamus amphibious, Chamaeleo dilepis, and Proatheris superciliaris, birds, such as Dendrocygna, Phalacrocorax africanus, Gallinula angulata, Porphyrio porphyrio, Plectropterus spp., Pelecanus spp., Bubulcus spp., Larus spp., and Diplachne fusca, and fish species, such as Barbus paludinosus, Barbus trimaculatus, Clarias gariepinus, and Oreochromis shiranus chilwae. For instance, Namazengeza pool is an important feeding ground for various aquatic biodiversity and is the thickest place in the river (Ambali and Kabwazi). Kabwazi and Wilson (1996) [13] reported that the presence of fish species in the deep pools was due to lake recession.

Some deep pools have been lost in just a few years as a consequence of changes in flow regimes and siltation [7]. Some have apparently become shallower due to increased silt deposition resulting from altered flow regimes after construction of the Mulunguzi Dam in the upper part of the catchment. Deep pool at Chigumukire in the river has gone from 3.85 meters deep to just 2.5 meters deep within the last ten years resulting in the extinction of many fish species.

\section{Conclusions}

Deep pools are recognized as important during lake recession and participatory fisheries management must be facilitated to sustain its fishery. Similar study must be conducted in the remaining rivers in order to have a broad understanding of the ecological aspect of Lake Chilwa basin during recession.

\section{Conflict of Interests}

The authors declare that there is no conflict of interests regarding the publication of this paper.

\section{Acknowledgments}

Support for the field work was provided by the Lake Chilwa Basin Climate Change and Adaptation Program with funding from the Royal Norwegian Embassy. The authors thank the local leaders for their generous support and effort during data collection.

\section{References}

[1] GoM, Review of the Fisher logbook data collection system under lake, Chilwa Basin Climate Change Adaptation Program, Lilongwe, Malawi, 2011.

[2] T. Nyasulu, W. Namoto, and O. C. Mponda, Analysis of Catch and Effort Data for the Fisheries Lake Chilwa 1976-1999, Fisheries Bulletin No. 49, Department of Fisheries, Lilongwe, Malawi, 2001.

[3] D. Jamu, M. Banda, F. Njaya, and R. E. Hecky, "Challenges to sustainable management of the lakes of Malawi," Journal of Great Lakes Research, vol. 37, no. 1, pp. 3-14, 2011.

[4] W. O. Mulwafu, "Conflicts over water use in Malawi: a socioeconomic study of water resources management along the Likangala River in Zomba District," in Proceedings of the 1st WARFSA/Water Net Symposium: Sustainable Use of Water Resources, Maputo, Mozambique, November 2000.

[5] W. O. Mulwafu and B. G. Nkhoma, "The use and management of water in the Likangala irrigation scheme complex in southern Malawi: some preliminary findings 233," in Proceedings of the 2nd WARFSA/Waternet Symposium: Integrated Water Resources Management: Theory, Practice, Cases, pp. 30-31, Cape Town, South Africa, October 2001.

[6] D. Jamu and J. Chimphamba, "Land use patterns in Likangala River Catchment and its implications for management of small watersheds in developing countries," Geophysical Research Abstracts, Vol. 7, 00248, European Geosciences Union, 2005.

[7] Environmental Affairs Department (EAD), Lake Chilwa Wetland Management Plan, Ministry of Natural Resources and Environmental Affairs, Malawi Government, 2001.

[8] M. D. Kalanda-Sabola, E. M. Henrey, E. Kayambazinthu, and J. Wilson, "Use of indigenous Knowledge and traditional practices in fisheries management: a case of Chisi Island, lake Chilwa, Zomba," Malawi Journal of Science and Technology, vol. 8, pp. 9-29, 2007.

[9] H. Moller, F. Berkes, P. O. Lyver, and M. Kislalioglu, "Combining science and traditional ecological knowledge: monitoring populations for co-management," Ecology and Society, vol. 9, no. 3, p. 2, 2004.

[10] F. J. Njaya, Review of Management Measures for LakeChilwa, Malawi: Final Project Fisheries Training Programme, United Nations University, 2001, http://www.unufp.is/fellows/view/ 172.

[11] E. H. Allison, "The fisheries sector, livelihoods and poverty reduction in Eastern and Southern Africa," in Rural Livelihoods and Poverty Reduction Policies, F. Ellis and H. A. Freeman, Eds., pp. 256-273, Routledge, London, UK, 2005. 
[12] M. De Wit and J. Stankiewicz, "Changes in surface water supply across Africa with predicted climate change," Science, vol. 311, no. 5769, pp. 1917-1921, 2006.

[13] H. H. Kabwazi and J. G. Wilson, "The Lake Chilwa environment," in A Report of the 1996 Ramsar Site Study, K. van Zegeren and M. P. Munyenyembe, Eds., p. 91, University of Malawi, Assemblies of God Literature Press, Zomba, Malawi, 1996. 

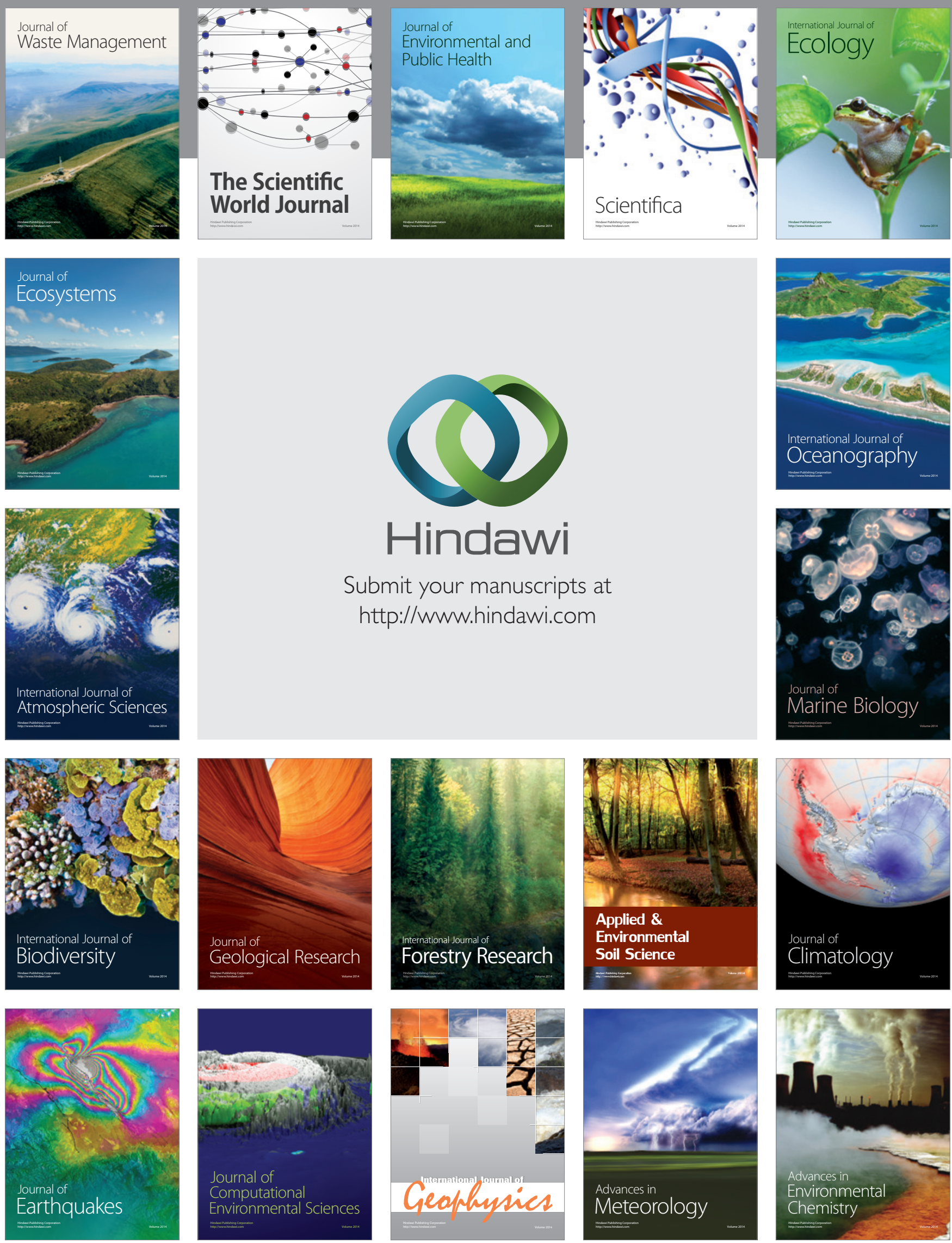